\title{
Lumen
}

Selected Proceedings from the Canadian Society for Eighteenth-Century Studies

\section{Canada's First Suburb: Transplanting the Villa to Early Québec}

\section{A. J. H. Richardson}

Volume 19, 2000

Material Productions \& Cultural Construction

Culture matérielle \& Constructions discursives

URI : https://id.erudit.org/iderudit/1012327ar

DOI : https://doi.org/10.7202/1012327ar

Aller au sommaire du numéro

Éditeur(s)

Canadian Society for Eighteenth-Century Studies / Société canadienne d'étude du dix-huitième siècle

ISSN

1209-3696 (imprimé)

1927-8284 (numérique)

Découvrir la revue

Citer cet article

Richardson, A. J. H. (2000). Canada's First Suburb: Transplanting the Villa to Early Québec. Lumen, 19, 225-241. https://doi.org/10.7202/1012327ar

Copyright (C Canadian Society for Eighteenth-Century Studies / Sociéte canadienne d'étude du dix-huitième siècle, 2000
Ce document est protégé par la loi sur le droit d'auteur. L'utilisation des services d'Érudit (y compris la reproduction) est assujettie à sa politique d'utilisation que vous pouvez consulter en ligne.

https://apropos.erudit.org/fr/usagers/politique-dutilisation/ 


\section{Canada's First Suburb: Transplanting the Villa to Early Québec}

In the best account of Québec City's nineteenth-century garden suburbs, L'Architecture et la nature à Québec au dix-neuvième siècle: les villas, France Gagnon-Pratte presents villas as a post-1780 development which took place almost entirely outside the town walls and mostly in la banlieue ('the league beyond the town') - the name of the western belt set up in the 1630 s.

Gagnon-Pratte recognized that the villa was not so much a specific form as an idea; it varied in form from period to period, and region to region. What typified villas from Roman antiquity to nineteenth-century Québec was a scale and level of comfort above the average, and an ample setting in close harmony with nature (11-13).

Understandably, such a thorough, definitive study of the Nineteenth Century could not explore closely the period before 1780 . As a result, it does not examine the now-crowded and walled Upper Town whose present antique-looking appearance gives the impression of always having been urban. At the same time, it dismisses the pre- 1780 houses in the suburbs beyond the wall as not being villas in any sense, but as the 'bourgeois architecture' of 'an urban milieu' erected by a 'peasant aristocracy' (5-7). For the whole of the French Régime it documents only one purely decorative garden that existed for some time before 1740 (8-9).

However, early suburban villas can be found, if we look in the right place. A careful study of pre-1759 development reveals that throughout that period nearly all the dense, urban huddle was confined to the Lower Town, and that the Upper Town, unwalled until after 1690, was then still an uncrowded suburb - the first and main one. Its airy layout was scattered with large, elegant convents and big houses which, though not very refined and lacking nineteenth-century size or detail, appear to have been conceived as villas in emulation of earlier models. Many of the gardens attached to these residences were extensive, serving ornamental purposes instead of, or in addition to, producing food. 
These discoveries should be no surprise, given that many of Upper Town's first residents were not peasants but urbane professionals in close touch with new developments and scientific horticulture in France during her 'Splendid Century' under Louis XIV's 'aristocracy of the gown.' In fact, from the very start of French colonization in Canada, at Acadia in 1604-05, the commandant at Port-Royal, Jean de Biencourt de Poutrincourt, was a cultured provincial noble, a soldier with 'a love for the finer things of life' (DCB, I, 96-99; Biggar \& Grant, II, 209). It was at his table that Champlain's 'chivalric' Order of Good Cheer met. His chief supporters and lieutenants were drawn from a complex and interlocking group of doctors, lawyers and officials in France that was beginning to invade and challenge the old 'aristocracy of the sword.' The picture is so full and clear, even in its background, that it is worth pausing to grasp its complexity so as to set the tone for what follows.

Among Poutrincourt's most important associates were Marc Lescarbot, two medical men - René-Pierre Chartier and Louis Hébert, and a geographer, Samuel de Champlain. The cultured Lescarbot had been Poutrincourt's lawyer in France, and was also a scholar, author, and poet (DCB, I, 469-71). Chartier was well connected at court; he was Physicianin-Ordinary to the king, a medical professor and author, and was related by marriage to a King's Surgeon Valet. Later, Chartier was a doctor to the daughters of Henri IV, even when they became Queens of Spain and England. Two of his sons were also medical professors. Although he never visited Acadia himself, he aided Poutrincourt's trading company from Paris, and even sent Lescarbot a scheme for further Canadian colonization. Hébert, by contrast, did join his cousin Poutrincourt and Lescarbot in Acadia. As an apothecary - by definition a skilled herbalist - who was the son of an apothecary, he took great pleasure in cultivating the soil at Port-Royal (DCB, I, 367)

Even Samuel de Champlain was married to the niece of a master surgeon; she had the added distinction of being a friend of an 'Apothecary of the King's Stables.' Hébert and Mme Champlain had grown up within three blocks of each other in Paris. For a time Champlain and Chartier lived on the same street; the latter was a guest at the wedding of Mme Champlain's sister (Le Blant, I, 250-51). Champlain 'took particular pleasure' in the gardens he and Hébert developed at St. Croix and Port-Royal, 'often resorting to them to pass the time.' This suggests they contained flowers as well as vegetables. An engraving in his Voyages shows them laid out decoratively, though an accurate survey indicates simple formality.

Champlain founded Québec in 1608. From the beginning, the settlement attracted people of considerable sophistication, a few at first and then in larger numbers later under his successors, the royal governors. 
In 1617 Hébert joined Champlain at Québec to become the first resident in the Upper Town and first farmer in Canada. Another medical man, naval surgeon Robert Giffard, established Canada's first settled seigneury just east of Québec City in 1634 (DCB, I, 330). Giffard's relatives the Juchereaus, who emigrated to Canada that same year, were lawyers. Champlain's interpreter, Jean-Paul Godefroy, was the son of a king's counsellor and Parisian treasurer-general (DCB, I, 339-41). Théodore Charles, who captained the fur fleet and lived in Québec off-and-on in the early 1630s, was a French provincial noble, like Poutrincourt.

The mix of sophisticated emigrants began to change under the governors, when a larger proportion of the settlers were lawyers, functionaries and nobles, perhaps reflecting new activity by the 'Hundred Associates,' the Canadian colonization company set up by Cardinal Richelieu. It was run by his deputy, Jean de Lauson, who was of a noble family which included many lawyers, treasurers, and other public officials $(D C B, \mathrm{I}$, 427). The first governor, Charles Huault de Montmagny, who served from 1636 to 1647, was a lawyer and relative of Lauson. The second, Louis D'Ailleboust de Coulonge, whose term extended from 1648 until 1651 , was a military engineer by training and came from yet another medical line; two of his forebears had been King's Principal Doctors (DCB, I, 42-43, 45).

D'Ailleboust was succeeded by Lauson himself, who during his term from 1651 to 1655 brought out a whole train of lawyers and lawyers-tobe. In his wake came his sons; two D'Amours of another family of lawyers who intermarried with the Lausons; his secretary Jean-Baptiste Peuvret Demesnu, a notary; Jacques Gourdeau de Beaulieu, son of a king's attorney in Poitou, the Lausons' native province; and LouisThéandre Chartier de Lotbinière (son of René Chartier), who had a career in Canada as attorney-general and judge in the Sénéchausée and Prévôté courts. Lotbinière's stepmother was a lawyer's daughter, his wife the stepdaughter of a rich Parisian lawyer and natural offspring of a D'Amours. Also prominent in the Prévôté court was the crown attorney Louis Boulduc, the son of a Parisian master apothecary-herbalist. He was married to the daughter of a Parisian lawyer who, in turn, may have been related to Jean de Peiras, yet another lawyer in Canada and himself the son of a lawyer. In 1662, shortly after Lauson's term ended, Claude Bermen de La Martinière, a lawyer like his kinsmen the Juchereaus, followed them to Québec.

Besides the Lausons and their relations, there were other emigrants who were, or had been linked to, public officials in France. Simon Denys de la Trinité was a lieutenant-civil at the King's salt granary at Tours (DCB, II, 261); Nicolas Dupont de Neuville's father had been receivergeneral for the same sort of facility in Picardy (DCB, II, 204). Also in 
Picardy, Charles Aubert de La Chesnaye's father held the post of intendant of fortifications in Amiens. The most famous of all newcomers to Canada, Jean Talon, had been intendant of the province of Hainault before he became intendant of Canada $(D C B, I, 615)$. Like Lauson, he was well-connected; two of the most prestigious lawyers in Paris were his cousins.

Other settlers or their relatives had held offices at the royal court itself, such as Denis-Joseph Ruette d'Auteuil, a King's General House Steward, and Louis Rouer de Villeray, whose father was a valet to the queen $(D C B$, $I, 579)$. While Villeray père may seem to have been a lower grade official, the son had enough influence at Court to force Frontenac to reinstate him after he was dismissed by the haughty governor.

Indeed, some of those who emigrated to Canada had connections with the very top administrators in the old country. For example, Lauson, Montmagny, Théodore Charles, the D'Amours and Bermens were distant relatives of the great Richelieu himself. Charles even used the additional surname 'Du Plessis-Bochart,' a combination of two names in the cardinal's family tree, in an attempt to borrow some of his lustre (DCB, I, 297). The Denys family had close business links with near-cousins of Nicolas Fouquet, who was briefly Louis XIV's all-powerful Superintendent of Finance. Talon, De Neuville, and the Nau de Fossambault sisters were twigs from the great family tree that held 'all the great offices of state' (Finance, Navy, Foreign Affairs and Colonies) during the middle years of Louis's reign (Goubert 278).

In addition, the early emigration to New France included a number of provincial squires. From Normandy in 1636 came the Legardeurs, who settled at Québec, and their relatives, the Le Neufs, who chose to go to Trois-Rivières instead. Pierre de Puiseaux appears to have emigrated from near Paris about the same time; Mme Gruel de La Peltrie from Normandy soon afterwards; François Chavigny de Berchereau from Champagne in the 1640s; and Olivier Morel de La Durantaye from Brittany some twenty years later. Several of the families which acquired distinction as judges and lawyers had been provincial nobles for a number of generations - the Huaults and the D'Amours since the Middle Ages - and had their roots in 'the aristocracy of the sword.'

We can see, then, that a great transatlantic network was already growing up between high-level officials in France and emigrants who remembered what a comfortable life they had enjoyed before setting out for Canada. Indeed, if proximity can be equated with familiarity, many who had lived near some of France's important new buildings and formal townscapes would have projected memories of them onto Québec. In Paris, Champlain, Hébert and Dr. Chartier had resided not much more than a stone's throw from the royal palace of the Louvre, its 
great classical wings soon to be extended under the direction of a cousin of Lauson and Montmagny. Boulduc had lived close by the QueenMother's Luxembourg Gardens, the 'first form of the Versailles style' in landscaping. The house of Montmagny's father had been on the site of the Place Royale (now Place des Vosges), the city's earliest formal square. A cousin of Talon's was one of the 'great magistrates' who inhabited mansions on the Île St. Louis, the city's new luxury quarter. Lotbinière himself had lived on its main street.

In the provinces, De Neuville grew up just twenty miles from Charleville's Place Ducale - an elegant, smaller version of the Place Royale (Plate 1). Gourdeau and some of the Lausons' cousins had homes forty miles or less from Richelieu's huge, formally designed country palace (second only to Versailles) and its neighbouring, planned village bearing the cardinal's name.

The many intermarriages in Canada between these people will have strengthened their class solidarity and tastes. During the late Seventeenth Century, 'Life was on the grand scale in the colony, and particularly at Québec, [where] ... the bourgeoisie gave in to the lure of luxury' $(D C B, \mathrm{I}, 138)$. Glimpses into the lives of a few of these men show how much they loved style, refinement and comfort. Clearly, Talon gladly accepted his titles of Count of Orsainville and Baron of Les Islets, taken from his seigneury and country-house near Québec. Lauson was a cultured man who possessed one of the finest libraries in France. According to the Journal des Jésuites, Lotbinière hosted 'the first ball in Canada' ('Pray God that nothing more may come of it!' commented the Jesuits) during the carnival season in 1667 (Thwaites, VIII, 16). After returning to Paris in his old age, he lived extravagantly beyond his means. Gourdeau designed a display of fireworks, 'such as scarcely seen in France,' to mark St. Joseph's Day, 1637, at Québec (Thwaites, VIII, 66). De La Chesnaye's house in the Lower Town, which was huge for Canada, had a mansard roof then in the height of French fashion, and a high-walled court like that of a Parisian hotel particulier. The Legardeurs had the reputation of being 'worthy gentlemen,' their women folk of being 'delicate young ladies.' De Puiseaux had grown quite wealthy from the West Indian trade.

Like other 'family compacts,' the Québec elite actively sought means to live in the same ease as in the old country. Profiting from trade monopolies, the elite also held nearly eighty per cent of seigneurial lands in Canada; the Lausons alone had a whopping 6,300,000 acres, including the whole Island of Montréal. It was often said that these men 'lived too well.'

Development of the Upper Town began when Champlain granted Louis Hébert a huge lot comprising nearly a quarter of the area now 
within the walls erected in 1690, but for long still decidedly suburban. Hébert put up a two-storey house there, but we know little of its character and nothing of its gardens. Still, he managed to live up to Champlain's expectations by labouring mightily as 'Canada's first farmer' and successfully growing a variety of crops. At Québec, Champlain himself developed gardens beside his two successive Lower Town trading posts erected in 1608 and 1626 . Of the first, we have only another over-elaborate, conventional rendering (Noppen, 4). But the latter has been recorded on a carefully-measured and probably reliable plan, its garden laid out in simple formal plots with a decorative centre piece (Bourdon).

The first royal governors took much more active steps to develop the Upper Town and western banlieue. In 1637, Montmagny ordered a radial grid of streets laid out for the Upper Town, through which ran a long, straight road known as the Grande Allée that may have been planned as a formal, processional way. Within this grid he gave very large lots to three religious communities, the Jesuits, the Ursuline nuns, and the Hôtel-Dieu sisters. At Sillery, on the outskirts of the western banlieue, he granted De Puiseaux a large property in a beautiful situation among fine oaks. Nearby, D'Auteuil and D'Ailleboust each secured fiefs of more than 200 acres, 'Monceaux' and 'Coulonge' respectively. The name of the former was taken from an estate near Paris that once belonged to D'Auteuil's late father-in-law. The latter recalled for D'Ailleboust an estate in France; he even went so far as to have his Québec 'Coulonge' formally recognized as a châtellenie (castle estate), suggesting perhaps that it was prime for a château or villa. Lauson was particularly active during his term as governor in granting lots within Montmagny's grid, chiefly on that part of the Grande Allée now within the walls and known as St. Louis Street. Ranging in size from 30,000 to 320,000 square feet, these lots were large enough to be developed into villas with gardens (Plate 2). Most of them were given to individuals who were members of the compact, such as the Legardeurs, Juchereau de Saint-Denis, Ruette d'Auteuil, Godefroy, Lotbinière, and D'Ailleboust.

Good contemporary plans and manuscripts show that from at least 1650 the development of residences there in the villa tradition was in full swing (Plate 3). Montmagny had set the tone for this in 1647 by building an official residence on the summit of the Upper Town's eastern cliff; his Château St. Louis had the basic elements of a villa. Eighty-seven feet long in stone, it had a classically low-pitched hip-roof but informal elevation and a full-length balcony from which the governor proudly showed his visitors, including Indian delegations, the famous panorama seen today from the Dufferin Terrace. Adjacent to the residence was a garden the size of a town block which, while protected by wall-turrets and bastions, 
was laid out formally. Since Montmagny liked its quietude and walked there with his Jesuit advisers, it was likely planted in flowers rather than cabbages.

Almost immediately after getting his fief at Sillery, De Puiseaux built a house there that, while not large, had gardens and was said by Dollier de Casson to be 'the jewel of the colony' $(D C B, \mathrm{I}, 558)$. It may have aspired to be a villa. Half a century later, a plan shows it with a big formal garden, but this may have been added by a later owner, the Séminaire de Québec (Bernier, 54). In 1651, D'Ailleboust had a house built for himself at 'Coulonge' and then 'spent the next years enlarging and beautifying' the property $(D C B, I, 45)$. D'Auteuil's 'Monceaux' was called a 'big house,' but perhaps this simply denoted the 'main house' on the estate.

In about 1660 De Villeray put together several lots much closer to the Upper Town (nearly opposite to where the legislative buildings now stand) to form a small estate, 'La Cardonnière' ('The Thistle Patch'). A plan of 1670 shows its buildings grouped formally beside a garden laid out symmetrically à la française (Plate 4). The garden was as large as the Governor's, and the house at least partly of stone. When enlarged by Villeray's successors soon after 1700 , the whole complex was made more elaborate, but these changes are beyond the scope of this article.

By 1670, each of the religious houses that had been granted big lots in the Upper Town was developing tall stone buildings there and gardens of the largest size and planned formality, with clusters of trees, perhaps orchards, and neatly treed alleys. The Hôtel-Dieu even had two big gardens. But some of the biggest houses and largest gardens in town, all formally patterned too, were appearing then on the medium-sized lots granted in the 1650s to laymen. Godefroy's house on St. Louis Street was 50 feet long; a Juchereau dwelling nearby and D'Auteuil's town house facing the Château St. Louis at the rift in the south-eastern cliff were both about 40 feet in length. Almost as long was the house put up by Guillaume Couillard as early as 1644 on the sizeable part of Hébert's vast lot inherited by Couillard's wife from her father. By 1670 it had one of the largest gardens of all. Though the property belonged by then to the Séminaire, likely the garden had been developed by Couillard because the priests had moved in barely a year earlier. On seventeenth-century plans of the town all these gardens appear with plots arranged in patterns, some with hooped alleys and stiff rows of trees. One is even shown with a single tree in what seems a faithful representation of reality. Another indication that most gardens were largely ornamental was their scale; Lotbinière's was much larger than required to supply the kitchen of a smallish house.

In a loop of the St. Charles tributary north of Québec, Talon began construction in 1667 on 'Les Islets,' an even more formal grouping of 
buildings and gardens. The contract for its erection described a mediumsized wooden house, but in a bird's-eye view of about 1690 by an anonymous artist it appears, perhaps only as a matter of artistic convention, with a hip roof and two wings. If a c.1670 drawing is to be credited, 'Les Islets' then had two courts of dependencies en suite, with an oval pond in each, steps to the river bank, and a flanking formal garden backed by a thicket of trees into which had been cut a semi-circular clearing, apparently for decoration (Plate 5).

The interior detail of these houses is documented as being much more than simply in a peasant-vernacular tradition. De La Chesnaye had a country house on the St. Charles, 'La Maison Blanche,' that by the 1680s was a two-storey building set beside a very large garden surrounded entirely by a wall. Although the house appears to have been very plain externally, there was in the second-storey parlour a stylish mantel with large roundel in the overmantel. It was almost identical in detail to a contemporary one found in the provinces in France which, in turn, was a simplified version of grander examples in the Palace of Versailles and another famous seventeenth-century château, Maisons-Lafitte, designed by François Mansart. A good drawing for La Chesnaye's mantel was made by Claude Baillif, a seventeenth-century Québec building contractor who is sometimes styled 'architect,' as was his brother in Paris (Plate 6).

There were many more examples of fine craftsmanship in Québec during this period. Baillif was frequently associated with Jean Le Rouge, who built a house for De Neuville with cut-stone quoins and surrounds. It also had a good mantel with polished cut-stone jambs; the joinery in the house was by Jean Levasseur, who had been a 'master joiner in Paris.' As early as 1650, Hébert's widow boasted a 'round stair' in her house. Godefroy's big house on St. Louis Street had four wooden mantels, eight double doors and a double-flight timber stair with 'balusters' that might well have resembled those on a surviving square-framed timber stair of the Seventeenth Century in the Ursuline Convent. The latter is very similar to slightly earlier examples in houses on the fashionable île St. Louis, Paris.

The roof of Talon's 'Les Islets' was hipped and slated. De Neuville's house also had a hip roof, quite probably with a low pitch in the classical style, like that on a house on the Côte de la Montagne, Québec, which may have been built for his cousin Talon. Since both D'Ailleboust, and Ruette d'Auteuil's stepfather Jean Bourdon, were skilled engineers, they might have provided plans of professional quality for 'Coulonge' and 'Monceaux.'

We can conjecture that life in these houses was enjoyable; one of Talon's had a wine pantry and cellar. We know that their occupants in 
some cases had the pleasure of living near other members of their families or work-associates. The Legardeurs and their in-laws, Godefroy and Juchereau, resided side-by-side on St. Louis Street. Across from them were houses in which, at different times, lived Lotbinière, his brother-in-law D'Amours, Jean Lemire (another brother-in-law of D'Amours), and three officials in the law courts: Gourdeau de Beaulieu, Demesnu and Boulduc. Mme de Beaulieu's late husband, Chavigny de Berchereau, may have dwelt previously just around the corner.

Hence, as early as the Seventeenth Century, a fashionable pattern of living on St. Louis Street and on adjacent streets was set for governors, acting governors, their lieutenants, councillors and council-clerks, lawyers and high legal officials, senior naval and military men. It persisted into the late Nineteenth Century.

As we have seen, already by 1670 many of the big Upper Town lots accommodated large houses with formal gardens. Forty years later little had changed in the basic layout of the quarter, although some dwellings had been replaced by bigger ones. By 1759, when the Upper Town began filling up at last, some much grander houses were built, such as the great stone house on the site of Juchereau's home where Montcalm died. Raised a storey again about 1800 , it still stands today. Truly it can be seen that the Upper Town suburb, now within the walls, was a bequest from the Seventeenth to the Eighteenth Century.

\section{A.J.H. RICHARDSON \\ Ottawa}

[Editorial Note: This paper, written by A.J.H. Richardson for delivery at the 1998 meeting of CSECS/SCEDS in Edmonton, draws upon the extensive research Mr. Richardson conducted during a long career in the public service. After fourteen years on the staff of the Public Archives of Canada, he joined what is now the National Historic Sites branch of Parks Canada in 1954 and was the senior historian there until his retirement in 1977. He revised this paper for publication with the assistance of Stephen A. Otto. The spellings of all proper names have been made to conform, where possible, to the Dictionary of Canadian Biography. Because the notes and works cited in the text do not encompass all the research the paper draws upon, a supplementary list of Works Consulted has been provided.] 


\section{Works Cited}

Bernier, André. Le Vieux-Sillery. Québec, 1977.

Biggar, H.P., and W. L. Grant (eds.). The History of New France by Marc Lescarbot. New York, 1968.

[Bourdon, Jean.] Plans of the First French Settlements on the Saint Lawrence, 1635-1642. Montréal, 1958.

Dictionary of Canadian Biography. English Edition. Toronto: Vol I (1966), Vol II (1969).

Gagnon-Pratte, F. L'Architecture et la nature à Québec au dix-neuvième siècle: les villas. Québec, 1980.

Goubert, Pierre. Louis XIV and Twenty Million Frenchmen. New York, 1970.

Le Blant, Robert and René Baudry. Nouveaux documents sur Champlain et son époque. Ottawa: Public Archives of Canada, Vol I (1967).

Noppen, Luc, C. Paulette, and M. Tremblay. Québec, trois siècles d'architecture. Québec, 1979.

Thwaites, R.G. The Jesuit Relations and Allied Documents. New York, 1898, Vols II \& VIII.

\section{Works Consulted}

\section{Printed}

American Historical Review, Vol.6 (1901).

Baudouin-Matuszek, Marie-N. Marie de Médicis et le Palais du Luxembourg. Paris, 1991.

Biggar, H.P. (ed.). The Works of Samuel de Champlain. Toronto: Champlain Society, Vols. III (1929), V (1932), VI (1936).

Bulletin des recherches historiques. Beauceville: Vols. 5 (1899), 9 (1903), 10 (1904), 21 (1915), 26 (1920), 28 (1922), 33 (1927), 38 (1932).

Les Cahiers des Dix. Montréal: Vols. X (1945), XV (1950), XVII (1952), XX (1955), XXVII (1962), XXXI (1966).

Cahiers d'histoire de la société historique de Québec. Québec: Vol. 13 (1961).

Campeau, Lucien. Établissement à Québec (1616-1634). Rome \& Québec: Monumenta Missionum Societatis Iesu, Vol. XXXVI, 1979.

. Fondation de la mission huronne (1636-1637). Rome \& Québec: Monumenta Missionum Societis Iesu, Vol. XLVI, 1987.

Couillard-Després, Azarie. La première famille française au Canada. Montréal, 1906.

De la Chenaye-Desbois et Badier. Dictionnaire de la noblesse. Paris: Vols. 3 (1863), 11

(1867), 12 (1868), 15 (1869), 16 (1870).

Dollier de Casson, François. Histoire de Montréal, 1640-1672. Montréal, 1868.

Doughty, A.G. and G. H. Parmelee. The Siege of Québec. Vol. III. Québec, 1901.

Fauteux, Aegidius. La famille d'Ailleboust. Montréal, 1917. 
Glénison, Jean. La France d'Amérique, voyages de Samuel de Champlain. Paris, 1994.

Griselle, E. État de la maison du roi Louis XIII. Paris, 1912. Supplément à la maison de Louis XIII. Paris, 1912.

Hautecoeur, Louis. Paris. Paris: F. Nathan, Vol. I (1972).

Hillairet, Jacques. Évocation du Vieux-Paris. Paris, Vol. I (1962).

Jean Bourdon, Plans of the first French settlements on the Saint Lawrence, 1635-1642. Montréal, 1958.

Jetté, René. Dictionnaire généalogique des familles du Québec. Montréal, 1983.

Le Journal des Jésuites, publié d'après le manuscrit original conservé aux Archives du Séminaire de Québec. Montréal, 1892.

Jugements et délibérations du conseil souverain de la Nouvelle France. Québec, 1886. Vol II.

Le Moine, J.M. Picturesque Québec. Montréal, 1882.

Mauricheau-Beaupré, Charles. Versailles. Monaco, 1948.

Mémoires de la société généalogique canadienne-française. Montréal: Vols. VI (1954), VIII (1957), IX (1958), XI (1960), XVI (1965), XVII (1966), XXII (1971), XXVIII (1977).

Morisset, Gérard. La vie et l'oeuvre du Frère Luc. Québec, 1944.

Noppen, Luc and Marc Grignon. L'Art de l'architecte. Québec, 1982.

Provost, Rév. H. Le Séminaire de Québec: Documents et Biographies. Québec, 1964.

[Series of documents in] Rapport de l'archiviste de la province de Québec pour 1957-58 et 1958-59. Québec, n.d.

Rélations des Jésuites, 1611-1672. Montréal: Vol. II (1972).

Révue de l'université Laval, Vol. 20 (1965).

Révue d'histoire de l'Amérique française, Vols. V (1951-52), IX (1955-56), XII (1958-59), XVII (1963-64), XXII (1968-69), XXIII (1969-70).

Roy, J.-Edmond. Histoire de la seigneurie de Lauzon. Lévis, 1897. Vol. I.

Roy, Pierre-Georges. Inventaire des concessions en fief et seigneurie. Beauceville, 1927. Vol. II.

. (later Antoine Roy). Inventaire des greffes des notaires du régime français. 4 vols. Québec, 1942-46. Inventaire d'une collection de pièces judiciaires. 2 vols. Beauceville, 1917. Vol. I. . La famille Godefroy de Tonnancour. Lévis, 1904.

La ville de Québec sous le régime français. 2 vols. Québec, 1930. Vol. I.

. Lettres de noblesse ... insinuées par le Conseil Souverain de la Nouvelle-France. Beauceville, 1920. Vols. I \& II.

. Papier terrier de la Compagnie des Indes occidentales, 1667- 1668. Beauceville, 1931.

Scott, Rév. Henri-Arthur. Notre-Dame de Sainte-Foy: Histoire civile re religieuse d'après les sources. [Québec], 1907. 
Souvenirs beaucerons de la famille Bolduc. Ottawa, 1938.

Sulte, Benjamin. Histoire des canadiens français. Montréal, 1882. Tome 4.

Tanguay, Rév. Cyprien. Dictionnaire généalogique des familles canadiennes. Québec: Vols. I (1871)\& III (1887).

Transactions of the Royal Society of Canada. 3rd series, Vol XXVI (1932).

Traquair, Ramsay. The Old Architecture of Québec. Toronto, 1947.

Trudel, Marcel. Catalogue des immigrants, 1632-1662. Montréal, 1983.

. Histoire de la Nouvelle-France. Montréal, 1983. Vol. III: La seigneurie des Cent-Associés, tomes $1 \& 2$.

. Le Québec de 1663. Québec, 1972.

. Le terrier du Saint-Laurent en 1663. Ottawa, 1973.

\section{Manuscripts}

Archives Nationales du Québec

Greffes [Notarial Registers] des notaires du régime français: Guillaume Audouart; Romain Becquet; Adrien Duchesne; Pierre Duquet; François Genaple; Jean-Antoine Panet; Martial Piraube; Gilles Rageot; Guillaume Tronquet.

National Archives of Canada, Microfilm reel C-12562 (originals in Paris, Archives nationales, Archives du Tabellionage)

National Archives of Canada, National Map Collections 


\section{Illustrations}

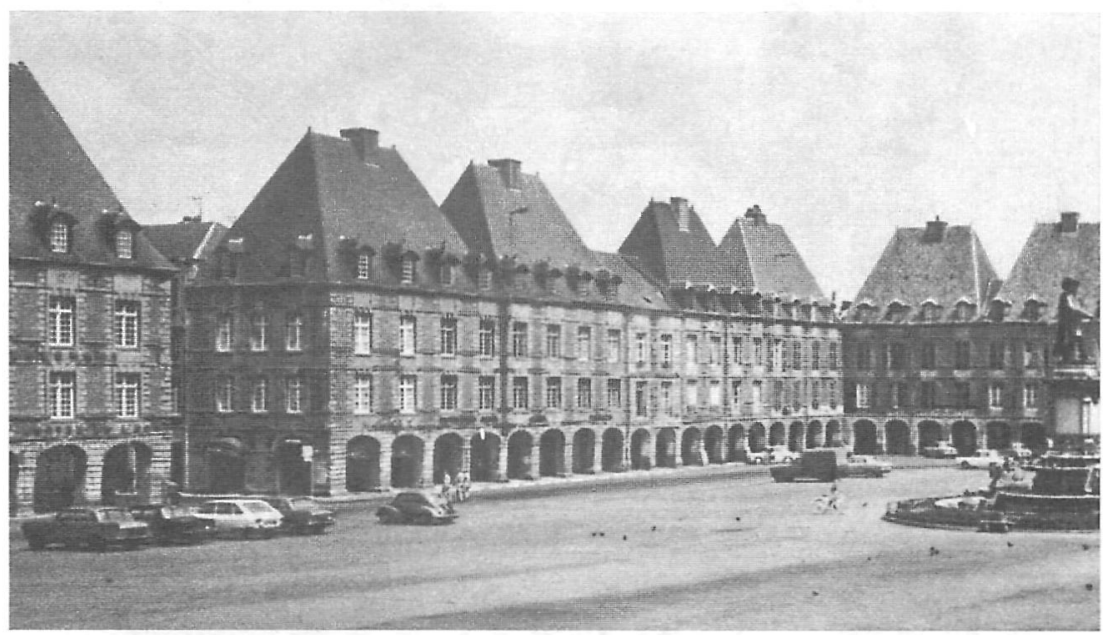

Plate 1 Place Ducale, Charleville. (Anon publication, author's collection)

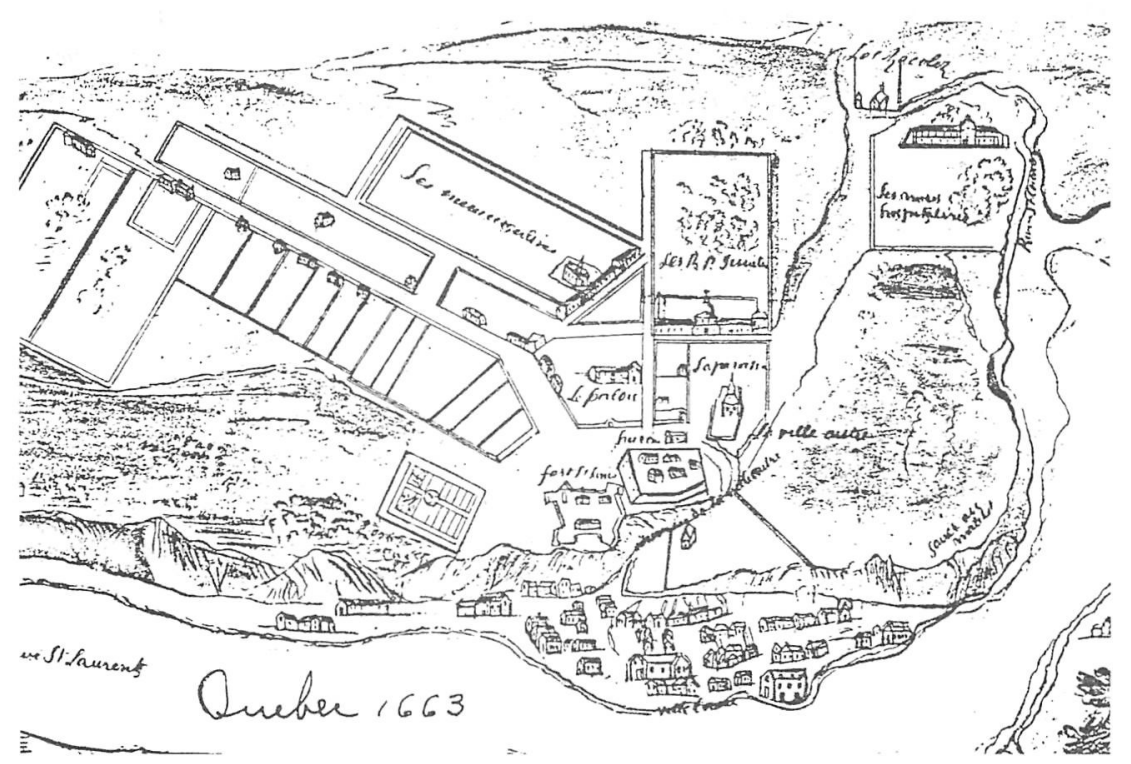

Plate 2 Plan de Québec fait en 1663, attribué à Jean Bourdon. (Inventaire des biuns culturels du Québec. Tiré de Concept Général de Réaménagement du Vieux-Québec par Cimon, De Blois, Gaumond et Robitaille (Août 1970). Original held at Versailles) 


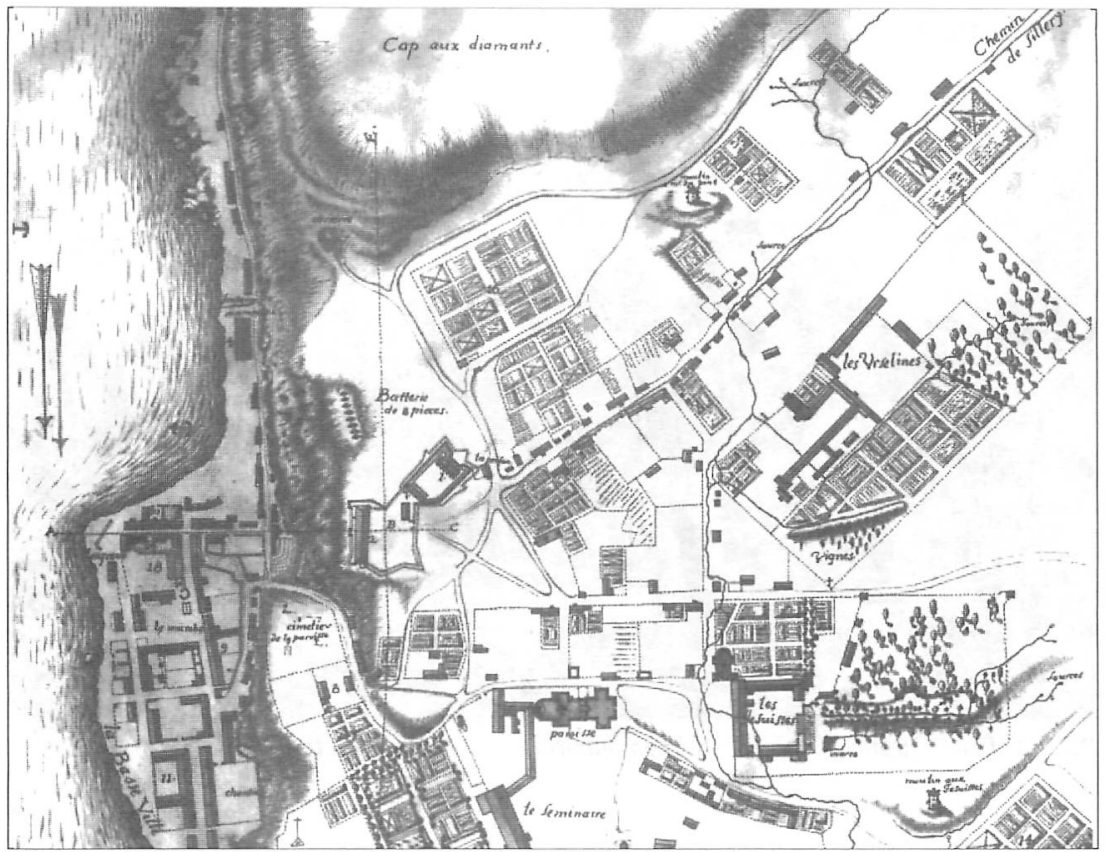

Plate 3 Plan de la ville, et chasteau de Quebec, fait en 1685, Mezurée exactement, par le Sr. devilleneuve. Detail (National Archives of Canada, NMC 16235; original held by Bibliothèque nationale, Centre d'archives outre-mer, Aix-en-Provence) 


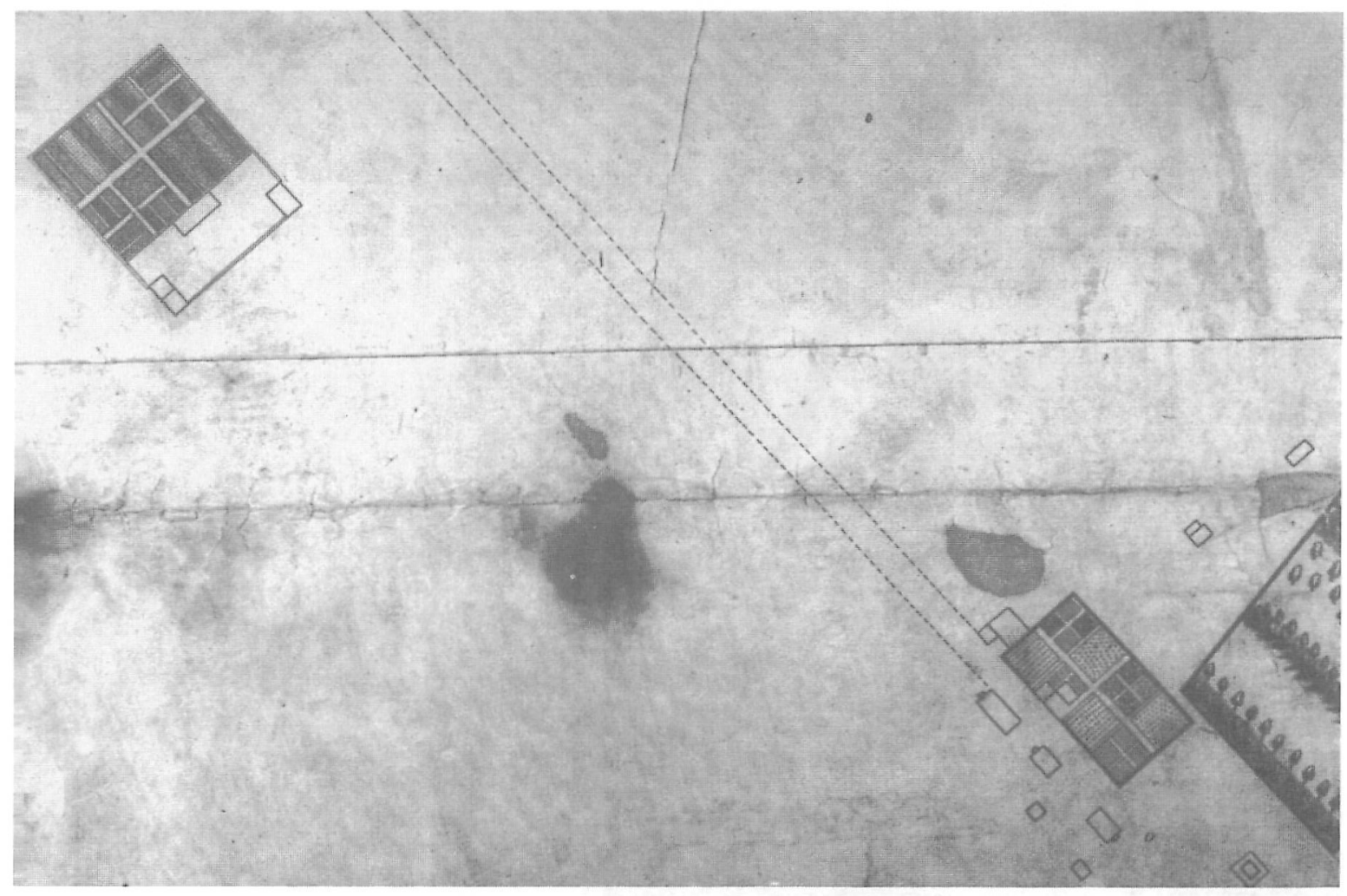

Plate 4 La Ville haute et basses de Quebek en la Nouvelle France, 1670. Anon. Detail showing 'La Cardonnière.' (National Archives of Canada, NMC 18302; original held by Archives nationales, Paris) 


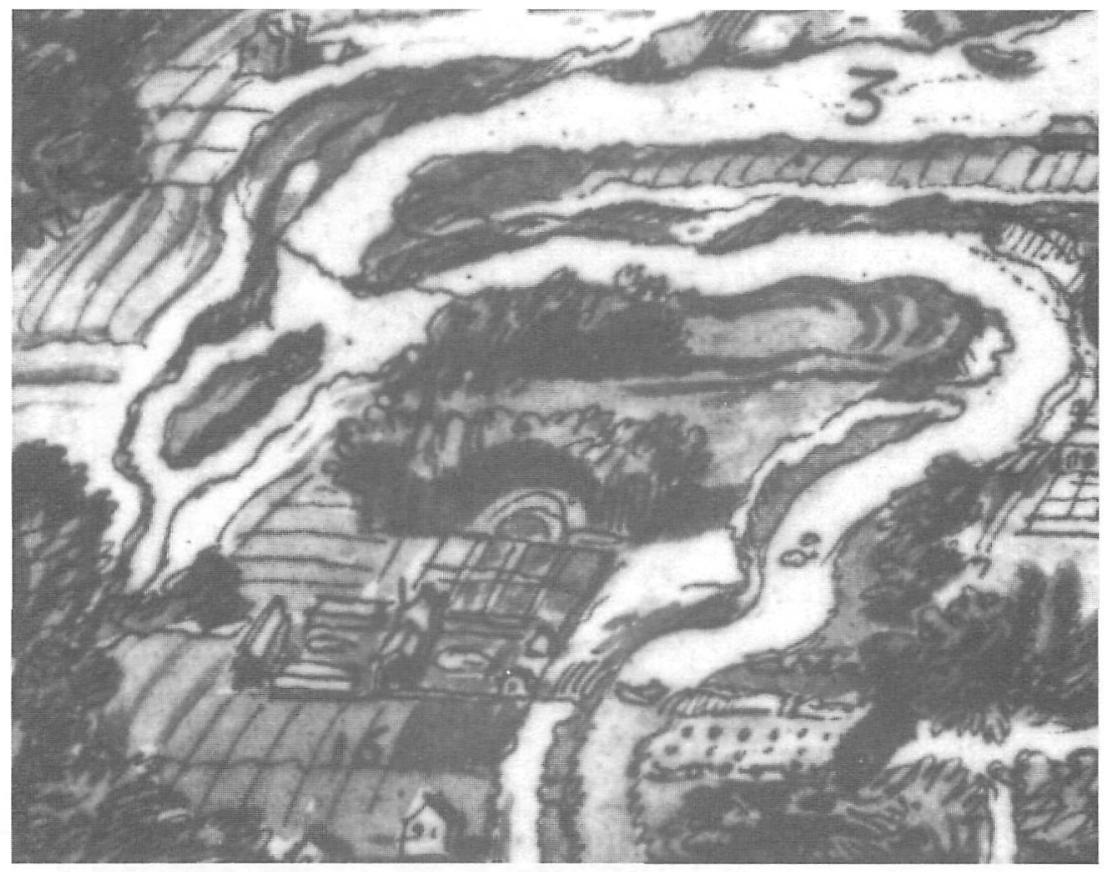

Plate 5 L'entrée de la Rivière de St-Laurent, et la ville de Québec dans le Canada. Anon. Circa 1690. Detail showing 'Les Islets,' seigneury of Jean Talon. (National Archives of Canada, NMC 5237; original held by Bibliothèque nationale, Dépôt des cartes et plans de la Marine, Service hydrographique, Paris) 


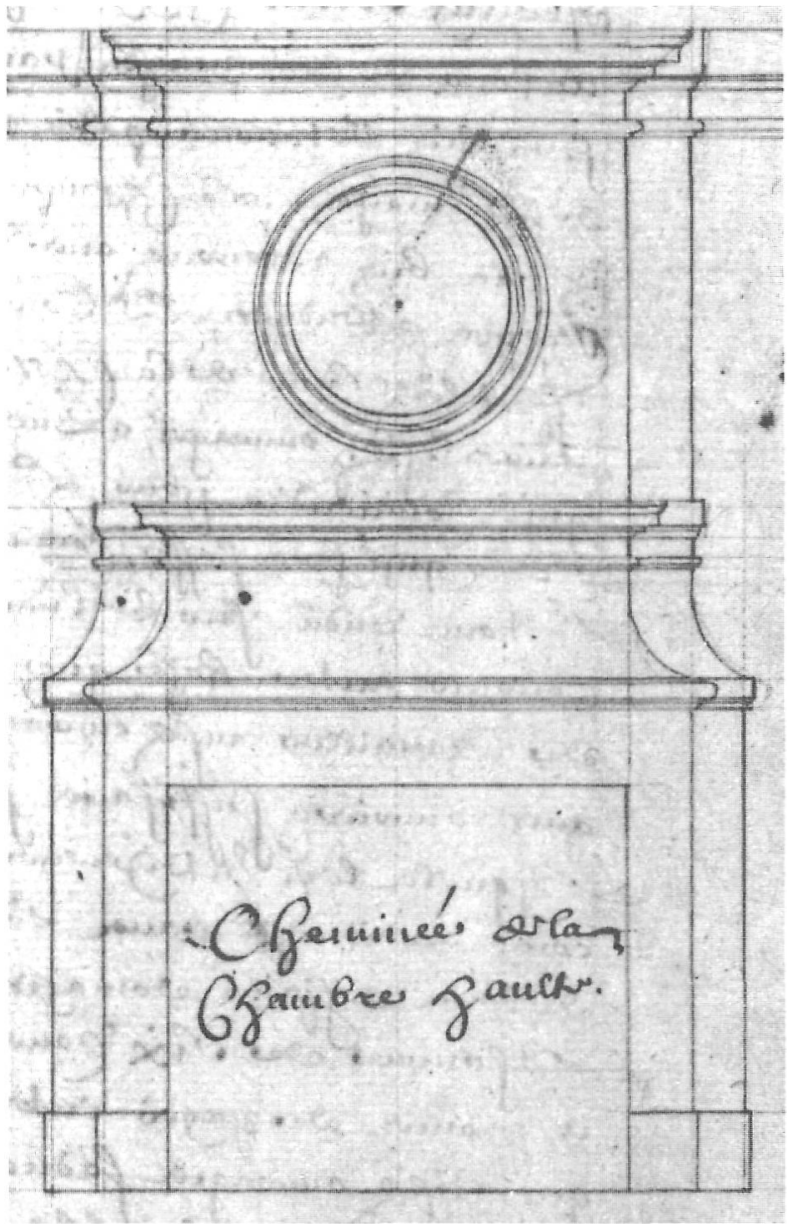

Plate 6 Mantel for 'La Maison Blanche,' Sillery, 1679. Drawn by Claude Baillif. (Archives nationales du Québec, fonds de Romain Becquet, contrat de 1 fév. 1679) 